\title{
Reintroduction of hand-reared alala Corvus hawaiiensis in Hawaii
}

\author{
C. Kuehler, P. Harrity, A. Lieberman and M. Kuhn
}

The wild alala Corvus hawaiiensis population has been declining for many years and only three pairs of birds are currently reproductively active on the island of Hawaii. At the recommendation of a committee formed by the National Academy of Sciences, a restoration programme was initiated in 1993 by The Peregrine Fund in collaboration with private land-owners, the US Fish and Wildlife Service, National Biological Service and the State of Hawaii. The restoration programme includes removing eggs from wild nesting birds for artificial incubation, handrearing and reintroduction. In two breeding seasons (1993, 1994), 17 eggs were removed from alala nests in the wild. Three eggs were infertile, 13 chicks hatched and 12 alala were successfully reared (hatchability: 93 per cent; survivability: 92 per cent). Four of these chicks were sent to the State of Hawaii's Olinda Endangered Species Propagation Facility, while four chicks from this facility were sent to the reintroduction programme. Twelve alala have been released by The Peregrine Fund: five in 1993 and seven in 1994. Three of the five birds released in 1993 and all seven of the birds released in 1994 are currently surviving in the wild.

\section{Introduction}

By virtue of their geographical isolation, unique forms of flora and fauna have evolved in the Hawaiian Islands. Hawaii has the highest percentage of endemic plant and animal species in the world and is home to more than one-third of the endangered species within the United States currently listed by the US Fish and Wildlife Service. Of the approximately 140 species of native birds that once inhabited the islands, 70 are now extinct and 30 are endangered, including 12 that are dangerously close to extinction (Pyle, 1990, 1992). During recent years, the continuing decline of many endemic species has reached the critical point, with population sizes of some endangered species numbering fewer than 100 individuals. Perhaps more alarming is that even the most common species are declining. For example, the iiwi Vestiaria coccinea, once abundant, may no longer survive on west Maui, Lanai or Oahu (Ellis et al., 1992). The factors limiting survival of these species in the wild are poorly understood but are believed to include the lack of immunity to introduced mosquitoborne diseases, habitat alteration, and predation by and competition with introduced species.

The alala, a frugivorous, forest-dwelling corvid, once inhabited large forested areas on the island of Hawaii. However, the species has been declining for many years and prior to the 1993 breeding season, only a remnant population of approximately 11 birds remained (Giffin et al, 1987). Wild breeding pairs have not produced a chick known to survive to adulthood in recent years (Kuehler and Shannon, 1994; P. Banko, pers. comm.).

In 1991 the US Fish and Wildlife Service (Service) requested the National Academy of Sciences to assess the situation and recommend a course of action to conserve the alala. This scientific panel reviewed the available data regarding the status of the species in the wild and the possible causes of decline. The committee recommended egg removal from wild birds for artificial incubation, hand- 
rearing and release (Duckworth et al., 1992). Artificial incubation of eggs removed from the wild, hand-rearing of chicks and the subsequent return of birds into their native habitat has been incorporated into the overall recovery strategy for endangered species such as the Mauritius kestrel Falco punctatus, peregrine falcon Falco peregrinus and San Clemente Island loggerhead shrike Lanius ludovicianus mearnsi (Sherrod et al., 1981; Cade et al., 1988; Jones et al., 1991; Kuehler et al., 1993). Successful techniques for hatching and rearing are essential elements of these recovery plans.

In 1993 the Service requested The Peregrine
Fund (TPF) to initiate a restoration programme for the alala in collaboration with private land-owners, National Biological Service (NBS) biologists, Service biologists and the State of Hawaii. Eggs were removed from wild nesting pairs for artificial rearing and juveniles were reintroduced into the wild.

\section{Methods}

\section{Artificial incubation and hand-rearing of alala}

In 1993 and 1994, 17 eggs were removed from wild nests by NBS, Service and TPF biologists

Table 1. Summary for hand-reared alala Corvus hawaiiensis reintroduced by The Peregrine Fund in Hawaii 1993-94

\begin{tabular}{|c|c|c|c|c|c|c|}
\hline $\begin{array}{l}\text { Wild } \\
\text { pair }\end{array}$ & $\begin{array}{l}\text { Egg } \\
\text { ID }\end{array}$ & $\begin{array}{l}\text { Date } \\
\text { hatched }\end{array}$ & Name & Sex & $\begin{array}{l}\text { Date } \\
\text { released }\end{array}$ & $\begin{array}{l}\text { Current } \\
\text { status }\end{array}$ \\
\hline \multirow[t]{7}{*}{ Kalahiki } & 1 & $4 / 19 / 93$ & Hiwa Hiwa & $\mathrm{F}$ & 23 Aug. 1993 & Alive \\
\hline & 2 & $4 / 21 / 93$ & Hoapili & $\mathbf{F}$ & 23 Aug. 1993 & Unknown \\
\hline & 3 & $4 / 23 / 93$ & Lokahi & $\mathrm{F}$ & 23 Aug. 1993 & Alive \\
\hline & 4 & - & Malposition & - & - & - \\
\hline & 5 & $7 / 4 / 93$ & Pomaikai & $\mathrm{F}$ & & To OESPF $7 / 15 / 93$ \\
\hline & 6 & - & Infertile & - & - & - \\
\hline & 7 & - & Infertile & - & - & - \\
\hline \multirow[t]{3}{*}{ Kealia } & 8 & $4 / 29 / 93$ & Malama & M & 23 Aug 1993 & Unknown \\
\hline & 9 & $4 / 29 / 93$ & Hulali & $\mathbf{F}$ & & To OESPF 6/18/93 \\
\hline & 10 & $5 / 1 / 93$ & Kehau & M & 23 Aug 1993 & Alive \\
\hline Kiilae & 11 & - & Infertile & - & - & - \\
\hline \multirow[t]{3}{*}{ Kalahiki } & 12 & $5 / 3 / 94$ & - & - & - & Died 5/10/94 \\
\hline & 13 & $5 / 4 / 94$ & Leinani & $\mathrm{F}$ & - & To OESPF $7 / 25 / 94$ \\
\hline & 14 & $5 / 5 / 94$ & Red 77 & $\mathrm{~F}$ & - & To OESPF $7 / 25 / 94$ \\
\hline \multirow[t]{7}{*}{ Kealia } & 15 & $5 / 19 / 94$ & Noe & $\mathrm{F}$ & 25 Oct. 1994 & Alive \\
\hline & 16 & $5 / 20 / 94$ & Paniolo & M & 25 Oct. 1994 & Alive \\
\hline & 17 & $5 / 21 / 94$ & $\mathrm{Lii}$ & $\mathrm{F}$ & 25 Oct. 1994 & Alive \\
\hline & - & $5 / 30 / 94$ & Hilu $^{*}$ & $\mathrm{~F}$ & 25 Oct. 1994 & Alive \\
\hline & - & $6 / 1 / 94$ & Mahoa* & M & 25 Oct. 1994 & Alive \\
\hline & - & $6 / 24 / 94$ & Kihapiilani* & $M$ & 25 Oct. 1994 & Alive \\
\hline & - & $6 / 26 / 94$ & Nanu $^{*}$ & $\mathrm{~F}$ & 25 Oct. 1994 & Alive \\
\hline
\end{tabular}

* Captive birds hatched at the Olinda Endangered Species Facility (OESPF).

Summary for wild eggs

Total eggs collected $\quad 17$

Total eggs fertile $\quad 14$

Total eggs infertile $\quad 3$

Total chicks hatched 13

Total chicks reared $\quad 12$

Hatchability $\quad 93 \%$

Survivability (30 days) $92 \%$ 


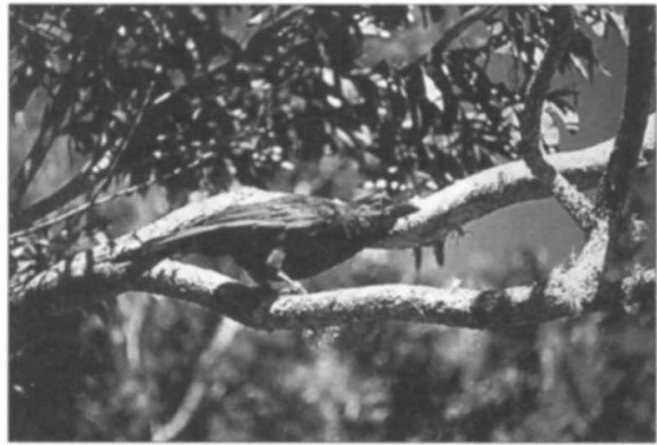

Young hand-reared alala Corous hawaiiensis perching on native koa Acacia koa shortly after release (Peter Harrity).

(Table 1). The eggs were candled in the field and transported to a temporary hatchery in Kona, Hawaii. Eggs were incubated and chicks reared using techniques developed at the Zoological Society of San Diego (Kuehler and Good, 1990; Kuehler et al., 1994). Puppets mimicking adult crows were used to feed chicks to minimize the possibility of abnormal imprinting or human socialization.

In 1993 two of the seven chicks produced from wild crows were transferred to the State of Hawaii's Olinda Endangered Species Facility (OESPF) for future captive breeding. In 1994 two additional offspring were transferred to the captive-breeding facility and four hand-reared juveniles produced from the captive flock were sent to the island of Hawaii for release. Alala from the captive flock were also reared to minimize imprinting and underwent the same release procedures as chicks reared from wild-laid eggs (G. Massey, pers. comm.).

\section{Release of alala}

The release structure for juvenile alala consists of a $2 \times 2 \times 2-\mathrm{m}$ wooden, mosquito-proof hack box built on a $3 \times 4 \times 5-\mathrm{m}$ tower platform. The hack box is enclosed within a $15 \times 30 \mathrm{~m}$ predator-proof aviary on ranch-leased land belonging to the State of Hawaii at an elevation of $1524 \mathrm{~m}$ in alala habitat. Four panels are removable; two in the front to allow release of birds into the aviary and two in the back, which allow the crows to be released to the

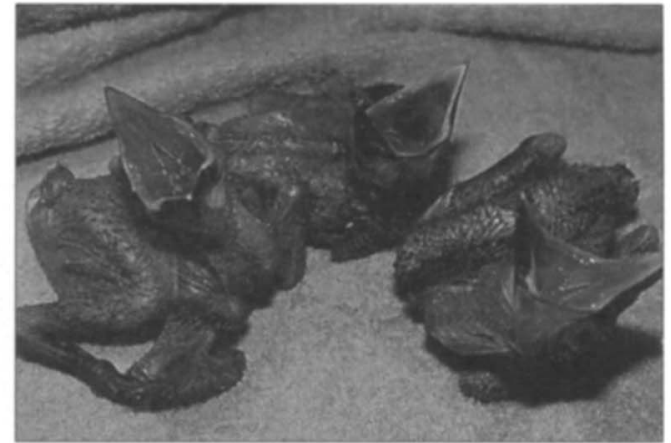

Nestling hand-reared alala Corvus hawaitensis (Cyndi Kuehler).

wild. On each side of the hack box is a $1.5 \times 2$ $\times 2$-m observation booth where crows inside the hack box and aviary can be monitored through one-way mirrors. Young alala were fed a diet consisting of papaya, crickets, dog food, eggs, mice and wild fruit once a day (Table 2). Until feeding independently the young birds were fed by a puppet through 0.3 $\times 0.3-\mathrm{m}$ food ports.

Young birds are transferred as clutch-mates from the temporary hatchery/brooder facility to the small hack box in the release structure at 46-63 days of age. Juveniles are allowed access to the aviary at 62-96 days of age; five alala were housed together in 1994 and seven in 1995. The aviary encloses native vegetation including fruiting trees and shrubs up to $15 \mathrm{~m}$ in height. The young birds become acclimatized to the sights and sounds of the forest and learn to forage on native food items in the aviary.

During the release process (3-5 months) mongoose Herpestes auropunctatus and rats Rattus rattus are trapped around the field aviary. Introduction from the aviary to the wild occurs at 121-157 days of age. The timing of release of birds is based on age, flight and foraging capabilities and behavioral interactions between the young birds and wild adult crows and the predatory hawk, io, Buteo hawaiiensis. For example, when all the young birds are capable of sustained flight (circling the interior of the enclosure) and are adept at eating berries growing wild in the aviary, the 


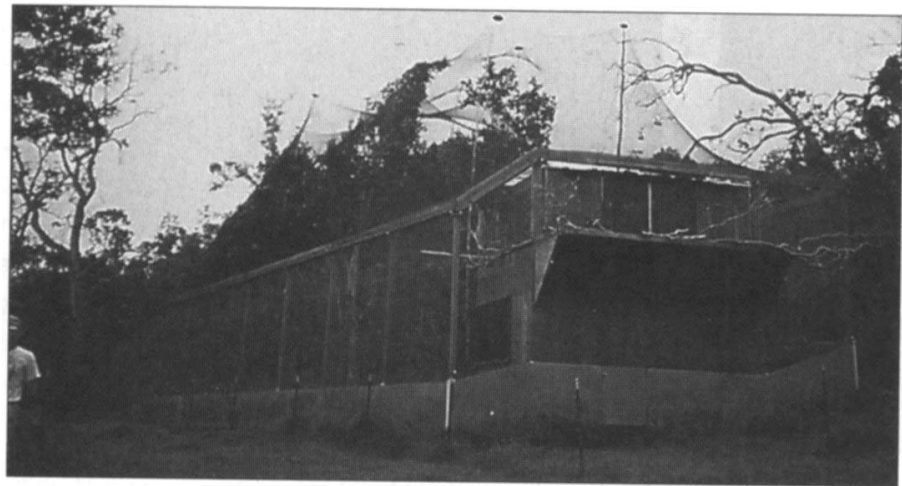

The release aviary in the South Kona Forest on the island of Hawaii (Alan Lieberman).

group is fit for release. Opening of the field aviary was delayed if threatening io or wild crows were in the immediate area.

After the aviary was opened birds were fed using two supplementary feeding stations, one placed $10 \mathrm{~m}$ from the aviary and a second placed at a distance of $25 \mathrm{~m}$. Weights and behaviour were monitored as food was slowly reduced over a 3-5-month period. Young alala did not disperse until supplementary feeding was completely discontinued.
Release techniques for alala are modified for frugivorous crows from release experiments with peregrine falcons (Cade et al., 1988). In 1993 tail-mounted transmitters were attached to released birds but two of the five transmitters were lost due to feather loss and breakage. In 1994 harness back-packs with teflon ribbons were selected. Transmitters were programmed to maximize battery life and transmit 16 hours daily for the first 90 days after release and subsequently every third day after this.

\begin{tabular}{llll}
\hline $\begin{array}{lll}\text { Plant species } \\
\text { Hawaiian name }\end{array}$ & Scientific name & $\begin{array}{l}\text { Preference } \\
\text { level }\end{array}$ & $\begin{array}{l}\text { Eaten after } \\
\text { release }\end{array}$ \\
\hline Akala & Rubus hawailensis & II & - \\
Hapuu & Cibotium glancum & - & $\times$ \\
Hoawa & Pittosporum hosmeri & III & - \\
Hoi kuahiwi & Smilax melastomifolia & II & - \\
Ieie & Freycinetia arborea & III & - \\
Kanawao & Broussaisia arguta & III & $\times$ \\
Kawau & Ilex anomala & II & $\times$ \\
Koa & Acacia koa & - & $\times$ \\
Kolea & Myrsine lessertiana & III & $\times$ \\
Mamaki & Pipturus albidus & III & $\times$ \\
Manono & Gouldia terminalis & I & - \\
Naio & Myoporum sandwicense & III & - \\
Oha kepau & Clermontia hawaiiensis & I & - \\
Ohe & Tetraplasandra melandra & III & $\times$ \\
Ohelo & Vaccinium reticulatum & I & $\times$ \\
Ohia & Metrosideros collina & II & $\times$ \\
Olapa & Cheirodendron trigynum & I & $\times$ \\
Pilo & Coprosma spp. & - & $\times$ \\
Thimbleberry & Rubus rosaefolius & II & - \\
\hline
\end{tabular}

Table 2. Ranking of wild plants preferred by captive alala and after release

I, most preferred, eaten regularly when food item presented; II, eaten occasionally when presented, often not eaten; III, least preferred, rarely eaten when presented. 
Young hand-reared alala Corous hawaiiensis on the forest floor at the release site (Peter Harrity).

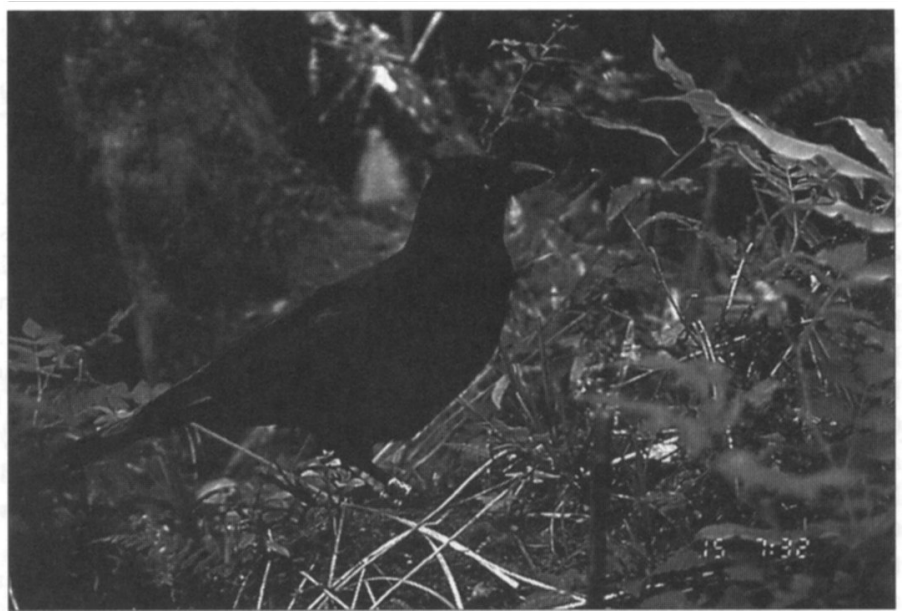

The birds are considered to be independent of the release process at approximately 250 days old when supplementary feeding is discontinued and they start to disperse. Monitoring and tracking of independent alala is supervised by NBS and Service biologists.

\section{Veterinary/pathology procedures}

In 1993 one egg removed from wild-nesting birds failed to hatch because of embryonic malpositioning. In 1994 one chick developed a yolk-sac infection and died at 1 week old (Rideout, 1993; Work, 1994). Prior to release, blood and feathers are collected for sexing and alala undergo a medical evaluation (Janssen, 1993; Massey, 1994a).

During August 1993, 40-50 per cent of mosquitoes trapped near the release aviary and analysed by Atkinson (NBS) tested positive for avian malaria. In September 1993 and 1994 hand-reared alala contracted avian pox and malaria. All birds were given veterinary support, recovered and were subsequently released (Massey, 1994a, b).

\section{Results}

To date, 17 eggs have been removed from alala nests in the wild. Three were infertile, 13 chicks hatched and 12 alala were successfully reared (hatchability: 93 per cent, survivability: 92 per cent). One egg failed to hatch in 1993 due to embryonic malpositioning and one chick died due to a yolk-sac infection.

Five birds were released in 1993 and seven in 1994. Four offspring of wild birds were exchanged with birds bred in captivity, making a total of 12 alala released resulting from field management efforts in 1993 and 1994.

Three of the five birds released in 1993 and all seven released in 1994 are currently surviving (29 November 1994). The status of two birds released in 1993 is unknown. The last sightings of Malama and Hoapili were at 10 months of age (February, 1994) and at 16 months of age (August, 1994), respectively (Table 1).

\section{Conclusions}

Alala restoration efforts including artificial incubation, hand-rearing and release on the island of Hawaii are continuing using techniques developed in 1993 and 1994. Artificial incubation of wild-laid eggs and subsequent hand-rearing is successfully producing release candidates and new genetic stock for the captive population. Reintroduced birds have survived for at least 19 months and continue to thrive. The final criteria for success of this programme are whether the released alala successfully reproduce in the wild. 


\section{Acknowledgements}

Many individuals and organizations have contributed to the success of this project. Our co-operators, including the US Fish and Wildlife Service, National Biological Service, Zoological Society of San Diego, the State of Hawaii Division of Forestry and Wildlife, and Greenfalk Consultants, and their many personnel who have contributed to the project have our very sincere thanks. In particular: Service Robert Smith, Karen Rosa, Scott Johnston, and Donna Ball; NBS - Paul Banko and Jim Jacobi; Olinda Endangered Species Facility - Peter Shannon and Greg Massey; Zoological Society of San Diego Nancy Harvey and Barbara Mcllraith; Greenfalk Consultants - John Marzluff. We also acknowledge the expertise and critical input from our veterinary advisors, Bruce Rideout, Don Janssen, Pat Morris, Carter Atkinson, Pat Redig, David Remple, Kenneth Riddle and Thierry Work. We thank the ranch owners and managers, Cynthia and Ray Salley as well as Keith Unger, Bobby McClure, Nick Zablan and Kamehameha Schools / Bernice Pauahi Bishop Estate - Peter Simmons, Tonnie Cassey, Doyal Davis and Bobby Lindsey. Finally, we acknowledge our colleagues at The Peregrine Fund - Linda Behrman, Frank Bond, Bill Burnham, Pat Burnham and Nancy Clum. This project was funded by the US Fish and Wildlife Service Pacific Island Ecoregion and The Peregrine Fund.

\section{References}

Cade, T.J., Enderson, J.H., Thelander, C.G. and White, C.M. (eds). 1988. Peregrine Falcon Populations: Their Management and Recovery. The Peregrine Fund, Inc., Boise, Idaho.

Duckworth, W.D., Cade, T.J., Carson, H.L., Derrickson, S., Fitzpatrick, J., James, F.C., Kuehler, C. and Pimm, S. 1992. The Scientific Bases for the Preservation of the Hawaiian Crow. National Academy of Sciences Press, Washington, DC.

Ellis, S., Kuehler, C., Lacy, R., Hughes, H. and Seal, U. 1992. US Hawaiian Forest Birds Conservation Assessment and Management Plan. Camp Proceedings, Dec. 7-12, 1992. Captive Breeding Specialist Group, IUCN-The World Conservation Union/Species Survival Commission.

Giffin, J. G., Scott, J.M. and Mountainspring, S. 1987. Habitat selection and management of the Hawaiian crow. Journal of Wildlife Management, 51, 485-494.

Janssen, D. 1993. Report on Veterinary Procedures on the Alala 15-18 June, 1993. Report to the US Fish and Wildlife Service and the Peregrine Fund Inc.

Jones, C. G., Heck, W., Lewis, R., Mungroo, Y. and Cade, T. 1991. A summary of the conservation management of the Mauritius kestrel Falco punctatus. Dodo, 27, 81-99.

Kuehler, C. and Good, J. 1990. Artificial incubation of bird eggs at the Zoological Society of San Diego. International Zoo Yearbook, 29, 118-136.

Kuehler, C. and Shannon, P. 1994. Alala Corvus hawaiiensis Studbook. The Peregrine Fund, Inc. and The Olinda Endangered Species Facility.

Kuehler, C.M., Lieberman, A., Mcllraith, B., Everett, W., Scott, T.A., Morrison, M.L. and Winchell, C. 1993. Artificial incubation and hand-rearing of loggerhead shrikes. Wildlife Society Bulletin, 21, 165-171.

Kuehler, C., Kuhn, M., Mcllraith, B. and Campbell, G. 1994. Artificial incubation and hand-rearing of alala Corvus hawaiiensis eggs removed from the wild. Zoo Biology, 13, 3.

Massey, G. 1994a. Trip Report, Alala Hacking Facility, August 1, 1994. Report to Olinda Endangered Species Facility.

Massey, G. 1994b. Veterinary Activities on the Big Island of Hawaii. September 23-24, 1994. Report to Olinda Endangered Species Facility.

Pyle, R.L. 1990. Native breeding birds of Hawaii. Elepaio, 50, 99-100.

Pyle, R.L. 1992. Checklist of the Birds of Hawaii. Honolulu, Bernice P. Bishop Museum, 1992.

Rideout, B. 1993. Alala Necropsy Report - 4/27/94. Report to Zoological Society of San Diego and U.S. Fish and Wildlife Service.

Sherrod, S.K., Heinrich, W.R., Burnham, W.A., Barclay, J.H. and Cade, T.J. 1981. Hacking: A Method for Releasing Peregrine Falcons and Other Birds of Prey. The Peregrine Fund, Inc., Fort Collins, Colorado.

Work, T.M. 1994. National Wildlife Health Research Center Alala Necropsy Report - 5/11/94. Report to the US Fish and Wildlife Service and The Peregrine Fund, Inc.

Cyndi Kuehler, The Peregrine Fund, PO Box 39, Volcano, Hawaii 96785, USA.

Peter Harrity, The Peregrine Fund, PO Box 844, Honaunau, Hawaii 96726, USA.

Alan Lieberman, The Peregrine Fund, PO Box 39, Volcano, Hawaii 96785, USA.

Marla Kuhn, The Peregrine Fund, PO Box 39, Volcano, Hawaii 96785, USA. 